\title{
GROWTH PERFORMANCE AND SOME BLOOD PARAMETERS OF GROWING JAPANESE QUAIL AS AFFECTED BY DIETARY TOTAL SULPHUR AMINO ACIDS LEVELS AND COPPER SUPPLEMENTATION
}

\author{
Engy Y. Abd Elsalam ${ }^{1 *}$, A.I. Attia ${ }^{2}$, Z.A. Ibrahim², D.E. Abou-Kassem ${ }^{2}$ and A.M. Abo-Taleb ${ }^{1}$ \\ 1.Poult. Res. Unit, Biol. Appl. Dept., Nuc. Res. Cent., Egyptian Atomic En. Authority \\ 2.Poult. Dept., Fac. Agric., Zagazig Univ., Egypt
}

\begin{abstract}
The present study has been conducted to investigate the effect of dietary total sulpher amino acids and copper administration on growth performance and some blood biochemical parameters of Japanese quail. A $3 \times 3$ factorial design was performed including three levels of total sulpher amino acids (TSAA) $(0.75,0.85$ and $0.95 \%)$ and three levels of copper $\left(\mathrm{CuSo}_{4}\right)$ supplementation $(0,100$ and $200 \mathrm{mg} / \mathrm{kg}$ diet) throughout the growing period (1-6 weeks of age). A total number of 405 unsexed one week old Japanese quail chicks were randomly distributed into nine treatment groups of 45 chicks each with 3 replicates of 15 chicks each. Chicks of all experimental groups had nearly the same initial average body weight and were not statistically different. Growth performance traits (live body weight (LBW), body weight gain (BWG), feed intake (FI) and feed conversion ratio (FCR)) were studied throughout the growing period. Results obtained indicated, significant $(\mathrm{P}<0.01)$ improvement in LBW at 6 weeks of age , BWG and FCR through 3-6 and 1-6 weeks of age in the group fed the diet containing $0.95 \%$ TSAA, comparing with those receiving $0.75 \%$ or $0.85 \%$ TSAA. Significant $(\mathrm{P}<0.05)$ decrease in FI was observed for the group fed the diet containing $0.75 \%$ TSAA through 1-6 weeks of age. Addition of copper to the diets of growing Japanese quail at levels 100 and $200 \mathrm{mg} / \mathrm{kg}$ diet, significantly improved all traits of growth performance comparatively with those receiving unsupplemented diets during 1-6 weeks of age. The interaction between diets containing $0.95 \%$ TSAA and $200 \mathrm{mg} \mathrm{Cu}$ Supplementation surpassed all other dietary treatments regard to all performance parameters. However, results showed that, TSAA level and copper supplementation had no significant effects on all carcass traits studied except only the gizzard. Blood contents of TP, Alb, Glb and glucose concentration significantly increased with the level of 0.95 and $0.85 \%$ TSAA, while there was no significant increase in A/G ratio among TSAA levels. Plasma protein profile did not show significant differences between the treatment groups at all levels of $\mathrm{CuSO}_{4}$ supplementation, while blood glucose had significantly increased with the level of 100 and $200 \mathrm{ppm}$ of $\mathrm{Cu}$. The activity of both AST and ALT significantly decreased at the level of 0.95\% TSAA than the other levels, also significant variations between control and other treatments in the ALP activity were recorded. The lowest activity of the previous enzymes was observed at the level of $100 \mathrm{ppm}$ copper sulphate, consequently it can be concluded that the levels of $0.95 \%$ TSAA and $200 \mathrm{mg}$ copper sulphate are safe in Japanese quail feeding. It can be concluded that supplementation of $\mathrm{Cu}$ at $200 \mathrm{mg} / \mathrm{kg}$ and the dietary TSAA at level $0.95 \%$ seemed to be the optimum levels. Chicks fed the diet containing $0.95 \%$ TSAA and $200 \mathrm{mg}$ copper $/ \mathrm{kg}$ diet had almost the best performance value, while the worst performance values were obtained in the group fed $0.75 \%$ TSAA without copper supplementation.
\end{abstract}

Key words Growth performance, blood biochemical, quails, TSAA, copper.

\footnotetext{
*Corresponding author: Tel. : +201096467438

E-mail address: waelengy@yahoo.com
} 


\section{INTRODUCTION}

The Japanese quail (Coturnix coturnix japonica) is a species of the old world that found in East Asia. The Japanese quail has played an active role in the lives of humanity since the $12^{\text {th }}$ century, and also plays major roles in industry and scientific research. Quail production has shown an increasing importance during the recent years because quails have early sexual maturity, rapid growth rate and small body size, which results in lower necessity of housing space and feed. The percentage content of edible meat in Japanese quail is very high. The birds are relatively easy to rear and suffer from very little maladies.

The total sulpher amino acids (TSAA) is consider to be the first limiting amino acid in broilers fed corn soybean meal diets. The NRC (1994) recommended a dietary TSAA level of $0.75 \%$ (9.5\% methionine) of diet for growing quail chicks up to 5 weeks of age. Methionine (Met) is an a-amino acid that is used in the biosynthesis of proteins. It is essential for the bird, meaning that the body cannot synthesize it and thus it must be obtained from the diet.

Copper $(\mathrm{Cu})$ is one of the essential trace minerals known to be important in poultry. Japanese quail nutritional requirement for copper is $8 \mathrm{mg} / \mathrm{kg}$ during starting, growing and finishing periods (NRC, 1994).

$\mathrm{Cu}$ has often been added to poultry diets as an antimicrobial and growth promoter for many years. The growth-promoting effect of $\mathrm{Cu}$ supplements has been reported by Skrivan et al. (2002) that supplementation with $200 \mathrm{mg} \mathrm{Cu} \mathrm{kg}$ diet increase final body weight of chickens by $4.3 \%$. Body weight increase of birds in the 100 ppm of copper treatments was $2.67 \%$ on average compared with control group (Kim et al., 2011). Copper supplementation at 125 to $250 \mathrm{ppm}$ has been shown to improve the growth rate and FCR in broiler chickens (Baker et al., 1991; Paik, 2001). $\mathrm{Cu}$ supplied as $\mathrm{CuSO}_{4} 5 \mathrm{H}_{2} \mathrm{O}$ is a cheap "inorganic antibiotic" that does not contribute to antibiotic resistance spreading among microorganisms. With increasing demands to move away from antibiotic treatments, $\mathrm{Cu}$ has become a very popular feed additive.
Also, copper is an essential mineral required for proper bone growth and development as well as enzyme functions. It is a component of various intracellular and extracellular enzymes, such as cytochrome oxidase, lysyl oxidase, ceruloplasmin and superoxide dismutase (Klasing, 1998). Dietary copper, when fed at physiological as well as pharmacological levels, has been demonstrated to alter the lipid metabolism of chickens (Bakalli et al., 1995). Metabolic changes resulting from dietary copper include changes in the rate of cholesterol biosynthesis and hepatic glutathione concentrations.

The relationship between TSAA and copper can be summarized in that, copper toxicity in chicks is moderated by increased dietary levels of sulfur amino acids (Jensen and Maurice, 1978). The mechanism by which sulfur amino acids interact with copper to reduce toxicity could encompass one or more of the following:

1) Reduced absorption of copper. 2) Formation of methionine or cysteine complexes with copper in vivo. 3) Increased synthesis of copper-binding proteins. 4) Enhanced biliary excretion of copper.

Studies with a purified crystalline amino acid diet (Robbins and Baker, 1980) indicated that the addition of 250 and $500 \mathrm{mg} / \mathrm{kg}$ copper increased the chick's sulfur amino acid (SAA) requirement by $13 \%$ and $30 \%$, respectively. Nonetheless, it is evident that high dietary copper levels increase the dietary requirement for these amino acids. Because typical cornsoybean meal diets for poultry are limiting in SAA and are routinely supplemented with 125 to $250 \mathrm{mg} / \mathrm{kg}$ copper, this effect could be of particular importance to poultry producers.Wang et al. (1987) also reported that, methionine requirement of broiler chicks increased when pharmacological levels of copper were fed to the broiler on high doses.

The present study aimed to investigate the effects of dietary TSAA level and copper supplementation on the growth performance, carcass traits and some blood parameters of Japanese quail chicks throughout the growing period (1-6 week of age). 


\section{MATERIALS AND METHODS}

The study was conducted at Poultry Research Unit, Biological Application Department, Radioisotopes Applications Division, Nuclear Research Center, Egyptian Atomic Energy Authority, Inshas area during the period between March to April, 2014.

\section{Experimental Design, Birds and Diets}

A 3x3 factorial design was performed including three levels of total sulpher amino acids $(0.75,0.85$ and $0.95 \%)$ and three levels of copper supplementation $(0,100$ and $200 \mathrm{~g} / \mathrm{kg}$ diet) through 1-6 weeks of age.

A total number of 405 unsexed one week old Japanese quail chicks were randomly distributed into nine treatment groups of 45 chicks each with 3 replicates each of 15 chicks. Chicks of all experimental groups had nearly the same initial average weight and were not statistically different.

Three basal experimental diets were formulated to cover the nutrient requirements for growing Japanese quail from 1-6 weeks of age according to NRC (1994). Diets were nearly isocaloricisonitrogenous and contain three levels of total sulpher amino acids (0.75, 0.85 and 0.95\%), Table 1. Each diet were fed without and with supplementation of copper sulphate $\left(\mathrm{CuSO}_{4}-\right.$ $5 \mathrm{H}_{2} \mathrm{O}$ ) to provide copper at the level 0,100 and $200 \mathrm{mg} / \mathrm{kg}$ diet for a total nine diets. Each experimental group of chicks, were allotted on one of the experimental diets.

Chicks were grown in brooders with raised wire floors and exposed to 24 hours of a constant light. Feed and water were supplied ad-libitum throughout the experimental period.

\section{Performance Traits}

The individual body weight (BW) and feed consumption (FC) were weekly recorded from the beginning of experiment till the six week of age. Then, the body weight gain (BW) was calculated at the same experimental periods. Also feed conversion ratio (FCR) was calculated as feed to gain ( $\mathrm{g}$ feed / $\mathrm{g}$ gain) ratio.

At the end of growing period (6 weeks of age), six birds were randomly chosen from each group, fasted overnight, weighed, then slaughtered by sharp knife to complete bleeding, and their feather were removed. At autopsy, the abdominal cavity was opened and the liver, heart and gizzard were removed. The eviscerated carcass were individually weighted and the carcass percentage was recorded.

\section{Blood Biochemical Analyses}

A total of 54 blood samples (six samples per each group) were collected at six weeks of age from the slaughtered chicks during their exsanguinations into heparinized waserman plastic tubes. Plasma samples were harvested after centrifugation of blood samples at 6000 rpm for 10 min using laboratory centrifuge. The blood glucose was determined, then the plasma were stored in a deep freezer at $-20^{\circ} \mathrm{C}$ until blood biochemical analyses. Plasma samples were assigned for determination of total protein (TP), albumin (Alb), aspartate aminotransferase (AST), alanine aminotransferase (ALT) and alkaline phosphatase (ALP) using available commercial kits. Globulin was calculated by subtraction of serum albumin from total protein.

\section{Statistical Analyses}

Data obtained were statistically analyzed on a 3x3 factorial design basis according to Snedecor and Cochran (1982) using SAS ${ }^{\circledR}$ software statistical analysis program (SAS, 1988) by adopting the following model:

$$
Y_{i j k}=\mu+A_{i}+S_{J}+A S_{i j}+e_{i j k}
$$

Where: $\mathrm{Y}_{\mathrm{ijk}}=$ an observation, $\mu=$ the overall Mean, $A_{i}=$ effect of copper level ( $i=1$ to 3 ), $S_{J}$ $=$ effect of total sulfur amino acids levels $(j=1$ to 3$), \mathrm{AS}_{\mathrm{ij}}=$ the interaction between total sulfur amino acids levels and copper levels (ij $=1$ to 9 ) and $\mathrm{e}_{\mathrm{ijk}}=$ random error. Differences among means within the same factor were tested using Duncan's New Multiple Rang test (Duncan, 1955).

\section{RESULTS AND DISCUSSION}

\section{Growth Performance}

\section{Live body weight and body weight gain}

\section{Total sulpher amino acid effect}

Regarding to LBW, obtained results in Table 2 reveal that, dietary TSAA levels had significant $(\mathrm{P}<0.05$ or $\mathrm{P}<0.01)$ effects on LBW at 3 and 6 
Table 1. Composition and calculated analysis of experimental diets

\begin{tabular}{|c|c|c|c|}
\hline \multirow[t]{2}{*}{ Item } & \multicolumn{3}{|c|}{ Sulfur amino acid level (\%) } \\
\hline & 0.75 & 0.85 & 0.95 \\
\hline \multicolumn{4}{|l|}{ Ingredient (\%) } \\
\hline Yellow corn & 52.77 & 52.67 & 52.57 \\
\hline Soybean meal (44\%) & 39.50 & 39.50 & 39.50 \\
\hline Corn-gluten meal (60\%) & 3.00 & 3.00 & 3.00 \\
\hline Cotton seed oil & 1.60 & 1.60 & 1.60 \\
\hline Di-calcium phosphate & 1.60 & 1.60 & 1.60 \\
\hline Limestone & 0.90 & 0.90 & 0.90 \\
\hline $\mathrm{NaCl}$ & 0.30 & 0.30 & 0.30 \\
\hline Premix * & 0.30 & 0.30 & 0.30 \\
\hline L-lysine HCL & 0.03 & 0.03 & 0.03 \\
\hline D- L methionine & - & 0.10 & 0.20 \\
\hline \multicolumn{4}{|l|}{ Calculated analysis ** } \\
\hline CP (\%) & 23.92 & 23.99 & 24.07 \\
\hline ME kcal/kg & 2885.11 & 2885.11 & 2885.11 \\
\hline Ca (\%) & 0.80 & 0.80 & 0.80 \\
\hline Avail, P (\%) & 0.46 & 0.46 & 0.46 \\
\hline Lysine (\%) & 1.31 & 1.31 & 1.31 \\
\hline Methionine (\%) & 0.42 & 0.52 & 0.62 \\
\hline Met.+ Cys. (\%) & 0.75 & 0.85 & 0.95 \\
\hline
\end{tabular}

* Vitamin and Mineral premix Each $2.5 \mathrm{~kg}$ consists of :

Vit A 12000, 000 IU; Vit D $, 2000,000$ IU; Vit. E. 10g; Vit k 2 g; Vit B 1,1000 mg ; Vit B 2 , 49g ; Vit B 6105 g; Vit B 12 , 10 mg; Pantothenic acid, 10 g; Niacin, 20 g , Folic acid , 1000 mg ; Biotin, 50 g; Choline Chloride, 500 mg, Fe, 30 g; Mn, 40 g; Cu, 3 g; Co, 200 mg; Si, 100 mg and Zn , 45 g.

** Calculated according to NRC (1994). 
Table 2. Average live body weight $(\overline{\mathbf{x}} \pm \mathrm{SE})$, $\mathrm{g}$ of Japanese quail chicks as affected by TSAA levels, copper supplementation and their interaction during the different experimental ages

\begin{tabular}{ccccc}
\hline \multicolumn{2}{c}{ Dietary treatments } & \multicolumn{3}{c}{ Age (week) } \\
\hline $\begin{array}{c}\text { TASS levels } \\
\mathbf{( \% )}\end{array}$ & $\begin{array}{c}\text { Copper } \\
\text { supplementation } \\
\text { (mg/kg diet) }\end{array}$ & $\mathbf{1}$ & $\mathbf{3}$ & $\mathbf{6}$ \\
\hline $\mathbf{0 . 7 5}$ & & $31.17 \pm 0.67$ & $104.43 \mathrm{~b} \pm 1.63$ & $213.46 \mathrm{c} \pm 1.79$ \\
$\mathbf{0 . 8 5}$ & & $30.73 \pm 0.33$ & $108.24 \mathrm{a} \pm 5.38$ & $222.81 \mathrm{~b} \pm 0.88$ \\
$\mathbf{0 . 9 5}$ & & $30.93 \pm 0.34$ & $101.04 \mathrm{c} \pm 4.28$ & $244.69 \mathrm{a} \pm 4.45$ \\
Significance & & $\mathrm{NS}$ & $*$ & $* *$ \\
& $\mathbf{0}$ & $31.20 \pm 0.42$ & $104.37 \pm 1.86$ & $220.30 \mathrm{c} \pm 3.62$ \\
& $\mathbf{1 0 0}$ & $30.79 \pm 0.34$ & $104.48 \pm 4.68$ & $225.58 \mathrm{~b} \pm 4.08$ \\
Significance & $\mathbf{2 0 0}$ & $30.83 \pm 0.59$ & $104.86 \pm 5.98$ & $235.09 \mathrm{a} \pm 6.65$ \\
Interactions (TASS levels & $\times \mathbf{C o p p e r ~ s u p p l e m e n t a t i o n ) ~}$ & & $* *$ \\
& $\mathbf{0}$ & $31.67 \pm 0.43$ & $108.43 \pm 3.08$ & $207.00 \mathrm{~h} \pm 1.41$ \\
$\mathbf{0 . 7 5}$ & $\mathbf{1 0 0}$ & $31.16 \pm 1.04$ & $104.13 \pm 2.68$ & $215.00 \mathrm{~g} \pm 0.86$ \\
& $\mathbf{2 0 0}$ & $30.69 \pm 1.51$ & $100.73 \pm 0.63$ & $218.39 \mathrm{fg} \pm 1.23$ \\
& $\mathbf{0}$ & $31.07 \pm 0.76$ & $105.66 \pm 2.70$ & $222.41 \mathrm{de} \pm 1.31$ \\
$\mathbf{0 . 8 5}$ & $\mathbf{1 0 0}$ & $30.53 \pm 0.23$ & $109.03 \pm 1.44$ & $220.38 \mathrm{ef} \pm 0.66$ \\
& $\mathbf{2 0 0}$ & $30.58 \pm 0.68$ & $110.03 \pm 8.22$ & $225.64 \mathrm{~d} \pm 0.31$ \\
& $\mathbf{0}$ & $30.87 \pm 0.40$ & $99.01 \pm 1.04$ & $231.50 \mathrm{c} \pm 0.18$ \\
$\mathbf{0 . 9 5}$ & $\mathbf{1 0 0}$ & $30.69 \pm 0.33$ & $100.28 \pm 11.97$ & $241.35 \mathrm{~b} \pm 2.19$ \\
& $\mathbf{2 0 0}$ & $31.22 \pm 0.98$ & $103.82 \pm 4.26$ & $261.22 \mathrm{a} \pm 1.75$ \\
& & $\mathrm{NS}$ & $\mathrm{NS}$ & $* *$ \\
\hline
\end{tabular}

Means in the same column within each classification bearing different letters are significantly different $(\mathrm{P}<0.05)$.

${ }^{*} \mathrm{P}<0.05,{ }^{* *} \mathrm{P}<0.01$ and NS $=$ Not significant

weeks of age. At 3 weeks of age, the average LBW of Japanese quail chicks fed on diets contained $0.75,0.85$ and $0.95 \%$ TSAA were 104.43, 108.24 and 101.04, respectively.

It could be noticed that, as dietary TSAA increase from 0.75 to $0.85 \%$ results insignificantly increase in LBW by $3.52 \%$. However, further increase dietary TSAA level from 0.85 to $0.95 \%$ resulted significantly $(\mathrm{P}<0.05)$ decrease in LBW by $6.65 \%$.

It is worth to note that, as dietary TSAA increase from 0.75 to $0.85 \%$ and $0.95 \%$ at 6 weeks of age resulted significantly $(\mathrm{P}<0.01)$ increase in LBW by 4.19 and $8.94 \%$ in chick diet contained 0.85 and $0.95 \%$ TSAA, respectively compared with those received $0.75 \%$ TSAA.

Concerning the DBWG, results in Table 3 revealed that, during 3 weeks of age, the average DBWG followed the same trend observed with LBW at 3 weeks of age, whereas, increasing dietary TSAA from 0.75 to $0.85 \%$ resulted insignificantly increase BWG by $11.42 \%$. However increase of dietary TSAA from 0.75 to $0.95 \%$ resulted significantly $(\mathrm{P}<0.05)$ decrease in BWG by $19.38 \%$. 
Table 3. Average daily body weight gain $(\overline{\mathbf{x}} \pm \mathrm{SE})$, g/day, of Japanese quail chicks as affected by TSAA levels, copper supplementation and their interaction during the growing periods

\begin{tabular}{|c|c|c|c|c|}
\hline \multicolumn{2}{|c|}{ Dietary treatments } & \multicolumn{3}{|c|}{ Period (week) } \\
\hline $\begin{array}{c}\text { TASS levels } \\
(\%)\end{array}$ & $\begin{array}{c}\text { Copper } \\
\text { supplementation } \\
\text { (mg/kg diet) }\end{array}$ & $1-3$ & $3-6$ & $1-6$ \\
\hline 0.75 & & $5.24 \mathrm{ab} \pm 0.12$ & $7.79 \mathrm{~b} \pm 0.23$ & $6.52 \mathrm{c} \pm 0.08$ \\
\hline 0.85 & & $5.92 \mathrm{a} \pm 0.39$ & $8.19 \mathrm{~b} \pm 0.37$ & $6.87 \mathrm{~b} \pm 0.04$ \\
\hline 0.95 & & $4.77 \mathrm{~b} \pm 0.30$ & $10.53 \mathrm{a} \pm 0.42$ & $7.65 \mathrm{a} \pm 0.16$ \\
\hline Significance & & $*$ & $* *$ & $* *$ \\
\hline & $\mathbf{0}$ & $5.23 \pm 0.119$ & $8.28 \pm 0.37$ & $6.76 \mathrm{c} \pm 0.14$ \\
\hline & 100 & $5.00 \pm 0.334$ & $8.92 \pm 0.57$ & $6.96 \mathrm{~b} \pm 0.15$ \\
\hline & 200 & $5.69 \pm 0.429$ & $9.31 \pm 0.69$ & $7.32 \mathrm{a} \pm 0.23$ \\
\hline Significance & & NS & NS & $* *$ \\
\hline \multicolumn{5}{|c|}{ Interactions (TASS levels $\times$ Copper supplementation) } \\
\hline & $\mathbf{0}$ & $5.44 \pm 0.249$ & $7.04 \pm 0.32$ & $6.24 \mathrm{~g} \pm 0.04$ \\
\hline \multirow{3}{*}{0.75} & 100 & $5.21 \pm 0.236$ & $7.92 \pm 0.19$ & $6.57 \mathrm{f} \pm 0.07$ \\
\hline & 200 & $5.07 \pm 0.105$ & $8.40 \pm 0.12$ & $6.74 \mathrm{e} \pm 0.10$ \\
\hline & $\mathbf{0}$ & $5.35 \pm 0.141$ & $8.34 \pm 0.18$ & $6.85 \mathrm{de} \pm 0.05$ \\
\hline \multirow[t]{2}{*}{0.85} & 100 & $5.61 \pm 0.111$ & $7.95 \pm 0.13$ & $6.78 \mathrm{e} \pm 0.02$ \\
\hline & 200 & $6.79 \pm 1.106$ & $8.28 \pm 1.11$ & $6.99 \mathrm{~d} \pm 0.03$ \\
\hline \multirow{3}{*}{0.95} & $\mathbf{0}$ & $4.92 \pm 0.103$ & $9.46 \pm 0.08$ & $7.19 \mathrm{c} \pm 0.01$ \\
\hline & 100 & $4.19 \pm 0.854$ & $10.89 \pm 1.00$ & $7.54 \mathrm{~b} \pm 0.08$ \\
\hline & 200 & $5.21 \pm 0.262$ & $11.24 \pm 0.41$ & $8.23 \mathrm{a} \pm 0.08$ \\
\hline Significance & & NS & NS & $* *$ \\
\hline
\end{tabular}

$\overline{\text { Means in the same column within each classification bearing different letters are significantly different }(\mathrm{P}<0.05) \text {. }}$

$* \mathrm{P}<0.05, * * \mathrm{P}<0.01$ and NS $=$ Not significant

During 3-6 weeks of age results obtained indicated significant $(\mathrm{P}<0.01)$ improvement in DBWG in the groups fed the diet contained $0.95 \%$ TSAA than those fed the diet containing 0.85 and $0.75 \%$ TSAA.

The same trend was observed, at the whole experimental period (1-6 weeks of age) where the results confirmed that diets contained $0.95 \%$ TSAA had beneficial effect than diets contained 0.75 or 0.85 TSAA.
In conclusion, the heaviest LBW and BWG values were recorded for birds fed diet contained 0.85 and $0.95 \%$ during $1-3$ and 3-6 weeks of age, respectively. This means that, these levels are adequate for growing Japanese quail throughout the growing period.

The results are in full agreement with Ibrahim and Abou-Kassem (2013) who studied the effect of interaction between copper sulfate and total sulfur amino acid levels on performance traits of growing Japanese quail 
and noticed that the highest body weight and BWG were recorded for the chicks fed $0.95 \%$ total sulfur amino acids compared with those fed $0.85 \%$ and $0.75 \%$ TSAA and also agree with Alagawany et al. (2014) who found significant effect $(\mathrm{P}<0.01)$ in body weight at 3 weeks of age and BWG during 7-12 day of age. In addition, Correa et al. (2006) demonstrated that meat type quail fed 0.95 and $0.73 \%$, methionine + cysteine diets during the initial period (7-21 days of age) and final period (22-42 days of age), respectively, showed maximum weight gain. Moreover, Kassim and Suwanpradit (1996) stated that, body weight gain of broiler chicks fed $0.79 \%$ and $0.86 \%$ TSAA were significantly higher $(\mathrm{P}<0.05)$ than those fed $0.72 \%$ TSAA at 6 weeks of age.

On the other hand, results obtained herein are disagree with Shrivastav and Panda (1986) who found that the body weight gain in Japanese quail recorded the maximum at $0.75 \%$ TSAA during 0-8 weeks of age. Also, Svacha et al. (1970) found that, the quail chicks needed 0.74\%TSAA for optimum growth from 0-3 weeks of age and Hassan (1999) found that, increasing TSAA up to $0.79 \%$ during finisher period by the addition of 0.15 DL- methionine resulted in non-significant effect on body weight and body weight gain.

\section{Copper supplementation effect}

In the view of the results of the whole experimental period (1-6 weeks of age), Table 2 and 3 , it could be noticed that, copper supplementation at the level of 100 or $200 \mathrm{mg} /$ $\mathrm{kg}$ to the diets of growing Japanese quail significantly $(\mathrm{p}<0.01)$ improved LBW at 6 weeks of age and BWG through 1- 6 weeks of age, compared with the unsupplemented one.

It is worth to note that, chicks fed diet supplemented with $200 \mathrm{mg}$ copper $/ \mathrm{kg}$ diet significantly increased $(\mathrm{P}<0.01)$ LBW at 6weeks by 2.40 and $6.71 \%$ and daily BWG by 3.00 and $8.30 \%$ during 1-6 weeks of age, respectively as compared with those fed diets without copper supplementation, respectively.

Accordingly, the supplementation of copper at level of $200 \mathrm{mg} / \mathrm{kg}$ diet seemed to be the optimum level owing to the best LBW and
BWG compared with that of $100 \mathrm{mg} / \mathrm{kg}$ diet and the unsupplemented one.

The different effects of dietary copper supplementation could possibly be explained through the action on the gut flora which might produce different levels of growth depressing infection.

These results are in agreement with Ibrahim and Abou-Kassem (2013) who studied the effect of interaction between copper sulfate and total sulfur amino acid levels on performance traits of growing Japanese quail and noticed that the body weight was higher in the group supplemented with $300 \mathrm{ppm}$ of $\mathrm{CuSO} 4$ followed by 200 and 100 ppm, Zahedi et al. (2014) demonstrated that, no significant results were observed on LBW and BWG in Japanese quail fed/diets supplemented with different levels of copper sulphate $(50,100,150$ and $200 \mathrm{mg} / \mathrm{kg})$ at any stage of the study, however Kassim and Suwanpradit (1996) showed that adding copper at $250 \mathrm{mg} / \mathrm{kg}$ to the diets resulted in small improvement of BWG of the growth broilers. In contrast, results obtained herein disagree with Karimi et al. (2011) who reported that, supplementing broiler diets with a higher level of (250 mg) during the starter period had a negative effect on LBW and BWG in broilers during the early days of the growth period. This negative effect is disappeared after (4 days of age).

However, it has been reported that levels of $\mathrm{Cu}$ higher than those currently recommended (NRC, 1994) did not have significant effects on broilers performance (Konjufa et al., 1997; Banks et al., 2004; Pang and Applegate, 2007; Chowdhury et al., 2004 ; Dozier et al., 2003).

\section{Interaction effect (dietary TSAA level $x$ Cu supplementation)}

Average LBW and BWG of Japanese quail chicks as affected by the interaction between dietary TASS level and copper supplementation are presented in Tables 2 and 3.

The interaction between TSAA and copper supplementation was significant $(\mathrm{p}<0.01)$ on LBW at 6 weeks of age and BWG through the period from 1-6 weeks. 
Chicks fed diet contained $0.95 \%$ TSAA with $200 \mathrm{mg} / \mathrm{kg}$ copper supplementation resulted in heaviest LBW at 6 weeks of age and DBWG through 1-6 weeks of age. The lowest LBW at 6 weeks of age and DBWG through 3-6 and 1-6 weeks of age were obtained when the chicks fed diets contained $0.75 \%$ TSAA without copper supplementation. This may be due to low nutrients digestibility.

The ability of TSAA to alleviate the growth depressing effect of copper had been reported by Jensen and Maurice (1979) and Christmas and Harms (1984) and was explained earlier by Robbins and Baker (1980) that compounds with free SH-groups (e.g. cystine and glutathione) readily chelate copper to form copper bond which cannot be easily dissociate. The formation of cystine copper chelate would also have the effect of lowering copper toxicity.

On the other hand, other investigators indicated that, statistical analysis failed to show any significant effects due to TSAA $\times \mathrm{Cu}$ with broilers during growing periods (Kassim and Suwanpradit 1996) thus, indicating that the TSAA was not the first limiting factor in the diets containing high copper level.

The results, shown above would support the concept that, Japanese quail chicks fed high dietary levels of copper increased SAA requirements. Jensen and Maurice (1978 and 1979) have suggested that increased need for SAA in the presence of excess copper is due in part, to increase copper excretion via SAA copper complexes.

\section{Feed Intake and Feed Conversion}

\section{Total sulpher amino acid effect}

With regard to feed intake, the obtained results in Table 4 show that, the different levels of TSAA had no significant effect on feed intake through the period of 1-3 weeks. However, during the periods from 3-6 and 1-6 weeks of age, indicated that, FI was increased with increasing dietary TSAA level from 0.75, 0.85 and $0.95 \%$. As dietary TSAA level increases from 0.75 to 0.85 and to $0.95 \%$, feed intake increased from 25.65 to 28.81 and 29.30, respectively during the period from 1-3 weeks of age and by 19.14 to 20.90 and 21.49 during the period from 1-6 weeks of age. It could be noticed that FI of birds fed on $0.85 \%$ or $0.95 \%$ TSAA had significantly $(\mathrm{P}<0.01)$ increased than those FI of fed $0.75 \%$ TSAA.

Concerning FCR, Table 5 show that, FCR was significantly affected due to TSAA level in the diets during all the experimental period. Significant improvement $(\mathrm{P}<0.01)$ in FCR ratio for the birds fed the diets containing $0.95 \%$ over 0.85 realized and $0.75 \%$ TSAA through the periods from 3-6 and 1-6 weeks of age.

These results agreed with those obtained by Ibrahim and Abou-Kassem (2013) who studied the effect of interaction between copper sulfate and total sulfur amino acid levels on performance traits of growing Japanese quail and found that FCR was the best with the level of $0.95 \%$ over 0.85 or $0.75 \%$ TSAA through $1-21$ and $21-42$ days of age, Alagawany et al. (2014) showed a significant improvement in feed conversion ratio for Japanese quail chicks fed diets containing $0.8 \%$ compared with chicks fed diet $0.9 \%$ TSAA during 7-21 days of age.

In contrary to our results, Alagawany et al. (2014) and El-Anwar and Attia (2005) on Japanese quails and broilers chicks, found that feed intake did not differ significantly by TSAA level in the diet. The results also disagree with those of Makled et al. (2001) who found insignificant effect due to methionine supplementation to corn soyabean diet for broiler chicks in access and greater than that need to meet the minimum NRC (1994) recommendation.

\section{Copper supplementation effect}

Regarding to feed intake through the periods from 1-3 and 3-6 weeks of age (Table 4), results show significant $(\mathrm{P}<0.05)$ improvement in FI during the period from 1-6 weeks of age as chicks received diets supplemented with copper (100 or $200 \mathrm{mg} / \mathrm{kg}$ diet) compared with unsupplemented one. Feed intake increased by 4.71 and $4.73 \%$ on the group of chicks fed diet supplemented with 100 and 200 copper $\mathrm{mg} / \mathrm{kg}$ diet respectively, compared with unsupplemented diet. 
Table 4. Average daily feed intake $(\overline{\mathbf{x}} \pm \mathrm{SE})$, $g$ of Japanese quail chicks as affected by TSAA levels, copper supplementation and their interaction during the growing periods

\begin{tabular}{ccccc}
\hline Dietary treatments & & & Period (week) & \\
\hline $\begin{array}{c}\text { TASS levels } \\
\text { (\%) }\end{array}$ & $\begin{array}{c}\text { Copper supplementation } \\
\text { (mg/kg diet) }\end{array}$ & $\mathbf{1 - 3}$ & $\mathbf{3 - 6}$ & $\mathbf{1 - 6}$ \\
\hline $\mathbf{0 . 7 5}$ & & $12.63 \pm 0.598$ & $25.65 \mathrm{~b} \pm 0.24$ & $19.14 \mathrm{~b} \pm 0.38$ \\
$\mathbf{0 . 8 5}$ & & $12.99 \pm 0.349$ & $28.81 \mathrm{a} \pm 0.23$ & $20.90 \mathrm{a} \pm 0.18$ \\
$\mathbf{0 . 9 5}$ & & $13.68 \pm 0.560$ & $29.30 \mathrm{a} \pm 0.38$ & $21.49 \mathrm{a} \pm 0.38$ \\
Significance & $\mathbf{N S}$ & $* *$ & $* *$ \\
& $\mathbf{0}$ & $12.03 \pm 0.299$ & $27.74 \pm 0.69$ & $19.89 \mathrm{~b} \pm 0.47$ \\
& $\mathbf{1 0 0}$ & $13.80 \pm 0.425$ & $27.84 \pm 0.54$ & $20.82 \mathrm{a} \pm 0.33$ \\
Significance & $\mathbf{2 0 0}$ & $13.46 \pm 0.611$ & $28.19 \pm 0.68$ & $20.83 \mathrm{a} \pm 0.54$ \\
Interactions (TASS levels & $\times \mathbf{C o p p e r ~ s u p p l e m e n t a t i o n )}$ & $\mathrm{NS}$ & $*$ \\
& $\mathbf{0}$ & $11.02 \mathrm{c} \pm 0.25$ & $25.14 \mathrm{c} \pm 0.12$ & $18.08 \mathrm{~d} \pm 0.147$ \\
$\mathbf{0 . 7 5}$ & $\mathbf{1 0 0}$ & $14.26 \mathrm{ab} \pm 1.11$ & $25.98 \mathrm{c} \pm 0.63$ & $20.12 \mathrm{bc} \pm 0.72$ \\
& $\mathbf{2 0 0}$ & $12.6 \mathrm{abc} \pm 0.61$ & $25.84 \mathrm{c} \pm 0.24$ & $19.22 \mathrm{~cd} \pm 0.413$ \\
$\mathbf{0 . 8 5}$ & $\mathbf{0}$ & $12.29 \mathrm{bc} \pm 0.31$ & $28.57 \mathrm{ab} \pm 0.31$ & $20.43 \mathrm{bc} \pm 0.28$ \\
& $\mathbf{1 0 0}$ & $13.56 \mathrm{ab} \pm 0.66$ & $29.13 \mathrm{ab} \pm 0.28$ & $21.35 \mathrm{ab} \pm 0.26$ \\
& $\mathbf{2 0 0}$ & $13.12 \mathrm{abc} \pm 0.72$ & $28.74 \mathrm{ab} \pm 0.62$ & $20.93 \mathrm{ab} \pm 0.11$ \\
$\mathbf{0 . 9 5}$ & $\mathbf{0}$ & $12.79 \mathrm{abc} \pm 0.28$ & $29.51 \mathrm{ab} \pm 0.53$ & $21.15 \mathrm{ab} \pm 0.13$ \\
& $\mathbf{1 0 0}$ & $13.59 \mathrm{ab} \pm 0.59$ & $28.40 \mathrm{~b} \pm 0.53$ & $20.99 \mathrm{ab} \pm 0.54$ \\
Significance & $\mathbf{2 0 0}$ & $14.66 \mathrm{a} \pm 1.57$ & $29.10 \mathrm{a} \pm 0.72$ & $22.33 \mathrm{a} \pm 0.96$ \\
\hline
\end{tabular}

Means in the same column within each classification bearing different letters are significantly different $(\mathrm{P}<0.05)$.

* $\mathrm{P}<0.05, * * \mathrm{P}<0.01$ and NS $=$ Not significant

Table 5. Average feed conversion ratio $(\overline{\mathbf{x}} \pm$ SE) of Japanese quail chicks as affected by TSAA levels, copper supplementation and their interaction during the growing periods

\begin{tabular}{|c|c|c|c|c|}
\hline \multicolumn{2}{|c|}{ Dietary treatments } & \multicolumn{3}{|c|}{ Period (week) } \\
\hline $\begin{array}{c}\text { TASS levels } \\
(\%)\end{array}$ & $\begin{array}{c}\text { Copper supplementation } \\
\text { (mg/kg diet) }\end{array}$ & $1-3$ & $3-6$ & $1-6$ \\
\hline 0.75 & & $2.42 \mathrm{ab} \pm 0.12$ & $3.32 \mathrm{~b} \pm 0.10$ & $2.94 \mathrm{a} \pm 0.05$ \\
\hline 0.85 & & $2.24 \mathrm{~b} \pm 0.10$ & $3.76 \mathrm{a} \pm 0.22$ & $3.04 \mathrm{a} \pm 0.04$ \\
\hline 0.95 & & $3.04 \mathrm{a} \pm 0.36$ & $2.82 \mathrm{c} \pm 0.11$ & $2.81 \mathrm{~b} \pm 0.05$ \\
\hline Significance & & $*$ & $* *$ & $* *$ \\
\hline & $\mathbf{0}$ & $2.31 \pm 0.09$ & $3.38 \pm 0.09$ & $2.94 \mathrm{ab} \pm 0.02$ \\
\hline & 100 & $2.94 \pm 0.37$ & $3.20 \pm 0.17$ & $3.00 \mathrm{a} \pm 0.07$ \\
\hline & 200 & $2.44 \pm 0.17$ & $3.32 \pm 0.30$ & $2.85 b \pm 0.05$ \\
\hline Significance & & NS & NS & $*$ \\
\hline \multicolumn{5}{|c|}{ Interactions (TASS levels $\times$ Copper supplementation) } \\
\hline & $\mathbf{0}$ & $2.04 \mathrm{~b} \pm 0.12$ & $3.59 \mathrm{ab} \pm 0.17$ & 2.90 bcde \pm 0.03 \\
\hline \multirow[t]{3}{*}{0.75} & 100 & $2.74 \mathrm{ab} \pm 0.15$ & $3.29 \mathrm{bc} \pm 0.12$ & $3.07 \mathrm{ab} \pm 0.13$ \\
\hline & 200 & $2.48 \mathrm{~b} \pm 0.09$ & $3.08 \mathrm{bc} \pm 0.02$ & $2.85 \mathrm{cde} \pm 0.02$ \\
\hline & $\mathbf{0}$ & $2.30 \mathrm{~b} \pm 0.04$ & $3.43 \mathrm{~b} \pm 0.10$ & $2.99 \mathrm{abc} \pm 0.06$ \\
\hline \multirow[t]{3}{*}{0.85} & 100 & $2.42 \mathrm{~b} \pm 0.15$ & $3.66 \mathrm{ab} \pm 0.09$ & $03.15 a \pm 0.04$ \\
\hline & 200 & $1.99 \mathrm{~b} \pm 0.19$ & $4.20 \mathrm{a} \pm 0.65$ & $2.99 \mathrm{abc} \pm 0.03$ \\
\hline & $\mathbf{0}$ & $2.61 \mathrm{ab} \pm 0.09$ & $3.12 \mathrm{bc} \pm 0.07$ & 2.94 bcd \pm 0.01 \\
\hline \multirow[t]{2}{*}{0.95} & 100 & $3.67 \mathrm{a} \pm 1.07$ & $2.65 \mathrm{c} \pm 0.21$ & $2.79 \mathrm{de} \pm 0.05$ \\
\hline & 200 & $2.84 \mathrm{ab} \pm 0.37$ & $2.68 c \pm 0.16$ & $2.72 \mathrm{e} \pm 0.12$ \\
\hline Significanc & & $* *$ & $* *$ & $* *$ \\
\hline
\end{tabular}

Means in the same column within each classification bearing different letters are significantly different $(\mathrm{P}<0.05)$.

* $\mathrm{P}<0.05$, ** $\mathrm{P}<0.01$ and NS = Not significant 
Concerning feed conversion ratio, response to copper supplementation for feed conversion ratio were not significant during the periods from 1-3 and 3-6 weeks of age. While, through the period from 1-6 weeks of age, it could be noticed that, significant was $(\mathrm{P}<0.05)$ in FCR was realized for the diet supplemented with 200 $\mathrm{mg} / \mathrm{kg}$ compared to those of $100 \mathrm{mg} / \mathrm{kg}$ diet and unsupplemented one. However, FCR was improved by 4.87 and $2.99 \%$ in chicks fed diet containing $200 \mathrm{mg}$ copper $/ \mathrm{kg}$ diet compared with those fed $100 \mathrm{mg}$ copper $/ \mathrm{kg}$ diet and unsupplemented one, respectively.

The present results are in agreement with those obtained by Pesti and Bakalli (1996), Ewing et al. (1998), Skrivan et al. (2000) and Karimi et al. (2011) who reported that, supplementation level of copper between 125 and $250 \mathrm{mg} / \mathrm{kg}$ diet improved FCR and FI. However, other investigators indicated that copper supplementation failed to obtain a significant effect on FI and FCR in broiler chicks (Robbins and Baker, 1980; Banks et al., 2004; Zahedi et al., 2014)

\section{Interaction effect (dietary TSAA level $x$ copper supplementation)}

The results reveal, highly significant $(\mathrm{P}<0.01)$ effect due to the interaction between TSAA level and copper supplementation (Tables 4 and 5).

It could be noticed that, during the whole experimental period (1-6 weeks), chicks fed diet contained $0.95 \%$ TSAA with $200 \mathrm{mg} / \mathrm{kg}$ copper had the best FI and FCR values. While, the poorest FI and FCR values were obtained by chicks fed the diet containing $0.75 \%$ TSAA without copper supplementation for FI and chicks fed diet containing $0.85 \%$ TSAA with $100 \mathrm{mg} / \mathrm{kg}$ copper supplementation for FCR.

These results are in agreement with those obtained by Kassim and Suwanpradit (1996) for FI, that there was a significant TSAA level $x$ copper supplementation interaction resulted from the decline in feed intake of the group fed basal diet, as opposed to the response of feed intake observed with the increasing dietary TSAA for the copper supplemented diets and also agreed with Robbins and Baker (1980) who found a significant copper $\times$ methionine interaction for gain and gain /feed ratio due to the addition of copper at $500 \mathrm{mg} / \mathrm{kg}$.

On the other hand, the results disagree with Ibrahim and Abou-Kassem (2013) who found that the interaction between total sulfur amino acid and copper sulfate revealed no significant differences in body weight and weight gain at 21 and 42 days. Besides, Kassim and Suwanpradit (1996) demonstrated that, statistical analysis failed to show the interaction between TSAA level $\times$ copper supplementation, thus, indicating that TSAA was not the first - limiting factor in the test diets containing high copper. It appeared that the normal level of $\mathrm{Cu}$ as copper sulphate did not interfere with TSAA requirements of the broiler chickens.

\section{Carcass Traits}

\section{Total sulpher amino acid effect}

Results in Table 6 show that, TSAA level had no significant effects on the carcass traits studied except only on gizzard weight, in which gizzard weight significantly decreased $(\mathrm{p}<0.05)$ by 13.21 and $1.52 \%$ in chicks fed diets containing $0.85 \%$ and $0.95 \%$ TSAA, respectively, compared to those having $0.85 \%$ TSAA.

The results are partially agree with these obtained by Alagawany et al. (2014), Fritts (2001) and Shrivastav and Panda (1986) who reported that dietary lysine and TSAA levels had no significant effects on same carcass traits for broilers and quail.

\section{Copper supplementation effect}

The parameters of carcass traits were not significantly affected among copper supplementation groups (Table 6).

Comparing the effect of copper supplementation with previous reports, Arias and Koustos (2006) supplemented $188 \mathrm{mg}$ of copper in broiler's diets, they reported that no significant effect was found on the carcass weight. Also, results obtained are in full agreement with those obtained by Waldroup et al. (2003) who did not observe any effect on the dressing percentage and edible carcass yield by supplementation of 55, 128 and $250 \mathrm{mg}$ from copper through copper sulphate. Similarly, Prajapati et al. (2012) reported that copper had no significant effect on liver, heart, gizzard and spleen. 
Table 6. Carcass traits $(\overline{\mathbf{x}} \pm \mathrm{SE})$ of Japanese quail chicks as affected by TSAA levels, copper supplementation and their interaction at 6 weeks of age

\begin{tabular}{|c|c|c|c|c|c|c|c|}
\hline \multicolumn{2}{|c|}{ Dietary treatments } & \multirow[t]{3}{*}{ Preslaughtered } & \multicolumn{5}{|c|}{ g/ 100 g pre-slaughter weight } \\
\hline \multirow[t]{2}{*}{$\begin{array}{c}\text { TASS levels } \\
(\%)\end{array}$} & \multirow{2}{*}{$\begin{array}{c}\text { Copper } \\
\text { supplementation } \\
\text { (mg/kg diet) }\end{array}$} & & & & & & \\
\hline & & & Carcass & Giblets & Liver & Gizzard & Heart \\
\hline 0.75 & & $215.00 \mathrm{c} \pm 3.11$ & $70.31 \pm 0.98$ & $5.852 \pm 0.15$ & $2.36 \pm 0.09$ & $2.61 \mathrm{a} \pm 0.12$ & $0.89 \pm 0.03$ \\
\hline 0.85 & & $237.89 \mathrm{~b} \pm 1.48$ & $69.34 \pm 0.66$ & $5.417 \pm 0.17$ & $2.32 \pm 0.12$ & $2.30 \mathrm{~b} \pm 0.07$ & $0.80 \pm 0.05$ \\
\hline 0.95 & & $250.17 \mathrm{a} \pm 2.45$ & $67.06 \pm 1.80$ & $5.572 \pm 0.16$ & $2.46 \pm 0.09$ & $2.27 \mathrm{~b} \pm 0.07$ & $0.85 \pm 0.03$ \\
\hline \multirow[t]{4}{*}{ Significance } & & $* *$ & NS & NS & NS & $*$ & NS \\
\hline & $\mathbf{0}$ & $227.44 \mathrm{c} \pm 5.56$ & $69.36 \pm 0.77$ & $5.72 \pm 0.15$ & $2.38 \pm 0.10$ & $2.469 \pm 0.0719$ & $0.87 \pm 0.02$ \\
\hline & 100 & $234.33 \mathrm{~b} \pm 5.49$ & $69.95 \pm 1.24$ & $5.53 \pm 0.21$ & $2.30 \pm 0.11$ & $2.383 \pm 0.1309$ & $0.86 \pm 0.03$ \\
\hline & 200 & $241.28 \mathrm{a} \pm 4.95$ & $67.40 \pm 1.66$ & $5.59 \pm 0.15$ & $2.46 \pm 0.09$ & $2.319 \pm 0.0955$ & $0.81 \pm 0.06$ \\
\hline \multicolumn{2}{|l|}{ Significance } & $* *$ & NS & NS & NS & NS & NS \\
\hline \multicolumn{8}{|c|}{ Interactions (TASS levels $\times$ Copper supplementation) } \\
\hline \multirow{3}{*}{0.75} & $\mathbf{0}$ & $206.33 \mathrm{~g} \pm 2.96$ & $70.60 \mathrm{a} \pm 0.15$ & $5.77 \pm 0.26$ & $2.26 \pm 0.11$ & $2.63 \mathrm{ab} \pm 0.14$ & $0.88 a b \pm 0.03$ \\
\hline & 100 & $213.67 \mathrm{f} \pm 4.05$ & $70.84 \mathrm{a} \pm 3.28$ & $6.00 \pm 0.21$ & $2.37 \pm 0.20$ & $2.74 \mathrm{a} \pm 0.285$ & $0.90 \mathrm{a} \pm 0.06$ \\
\hline & 200 & $225.00 \mathrm{e} \pm 1.44$ & $69.49 a b \pm 0.48$ & $5.79 \pm 0.35$ & $2.45 \pm 0.17$ & $2.45 \mathrm{ab} \pm 0.22$ & $0.89 a b \pm 0.06$ \\
\hline \multirow{3}{*}{0.85} & $\mathbf{0}$ & $233.50 \mathrm{~d} \pm 2.25$ & $69.22 \mathrm{ab} \pm 1.11$ & $5.63 \pm 0.34$ & $2.35 \pm 0.27$ & $2.41 \mathrm{ab} \pm 0.08$ & $0.87 a b \pm 0.03$ \\
\hline & 100 & $240.33 \mathrm{c} \pm 2.46$ & $69.87 \mathrm{ab} \pm 1.94$ & $5.21 \pm 0.35$ & $2.16 \pm 0.22$ & $2.22 \mathrm{~b} \pm 0.09$ & $0.83 a b \pm 0.05$ \\
\hline & 200 & $239.83 \mathrm{~cd} \pm 0.88$ & $68.94 a b \pm 0.14$ & $5.41 \pm 0.28$ & $2.44 \pm 0.20$ & $2.28 \mathrm{ab} \pm 0.18$ & $0.70 \mathrm{~b} \pm 0.14$ \\
\hline \multirow{3}{*}{0.95} & $\mathbf{0}$ & $242.50 c \pm 1.53$ & $68.27 \pm 2.12$ & $5.77 \pm 0.29$ & $2.53 \pm 0.17$ & $2.37 \mathrm{ab} \pm 0.13$ & $0.87 a b \pm 0.03$ \\
\hline & 100 & $249.00 \mathrm{~b} \pm 0.29$ & $69.14 \mathrm{ab} \pm 1.77$ & $5.39 \pm 0.38$ & $2.36 \pm 0.22$ & $2.20 \mathrm{~b} \pm 0.15$ & $0.83 a b \pm 0.07$ \\
\hline & 200 & $259.00 \mathrm{a} \pm 0.87$ & $63.77 \mathrm{~b} \pm 4.78$ & $5.56 \pm 0.20$ & $2.48 \pm 0.13$ & $2.23 \mathrm{~b} \pm 0.12$ & $0.85 a b \pm 0.05$ \\
\hline
\end{tabular}

Significance

$$
* *
$$

NS

NS

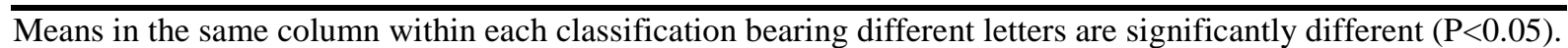
$* \mathrm{P}<0.05, * * \mathrm{P}<0.01$ and $\mathrm{NS}=$ Not significant

\section{Interaction effect (dietary TSAA level $x$ copper supplementation)}

The interaction effects due to dietary TSAA level and copper supplementation at the end of experimental period are given in Table 6.

No significant interaction effects were found between dietary TSAA level and copper supplementation in giblets and liver, however there were significant effects in carcass, gizzard and heart.

\section{Blood Parameters}

\section{Protein and its fractions}

\section{Total sulpher amino acid effect}

Significant differences have been recorded in total protein, albumin and globulin concentrations with TSAA level (Table 7). It could be noticed that birds fed $0.85 \%$ or $0.95 \%$
TSAA showed significantly $(\mathrm{P}<0.01)$ higher values than those having $0.75 \%$ TSAA. On the other hand, no significant differences were observed in A / G ratio with TSAA level.

The present results confirmed those obtained by Ibrahim and Abou-Kassem (2013) who concluded that there were significant differences in TP and Alb with 0.95 and $0.85 \%$ TSAA. While, insignificant differences in Glb and A/G ratio were obtained. In this connection Saki et al. (2015) noticed that total protein was significantly increased by treatment containing $0.35 \%$ of methionine and in contrast, this parameter was decreased by $0.25 \%$ of methionine. However, the results denied by Chattopadhyay et al. (2006) who reported that plasma concentration of total protein at both 21 and 42 day were similar $(\mathrm{P}>0.05)$ between the treatments. 
Table 7. Average values of some biochemical parameters $(\overline{\mathbf{x}} \pm \mathrm{SE})$ of Japanese quail as affected by sulfur amino acids levels, copper supplementation and their interactions during the growing periods

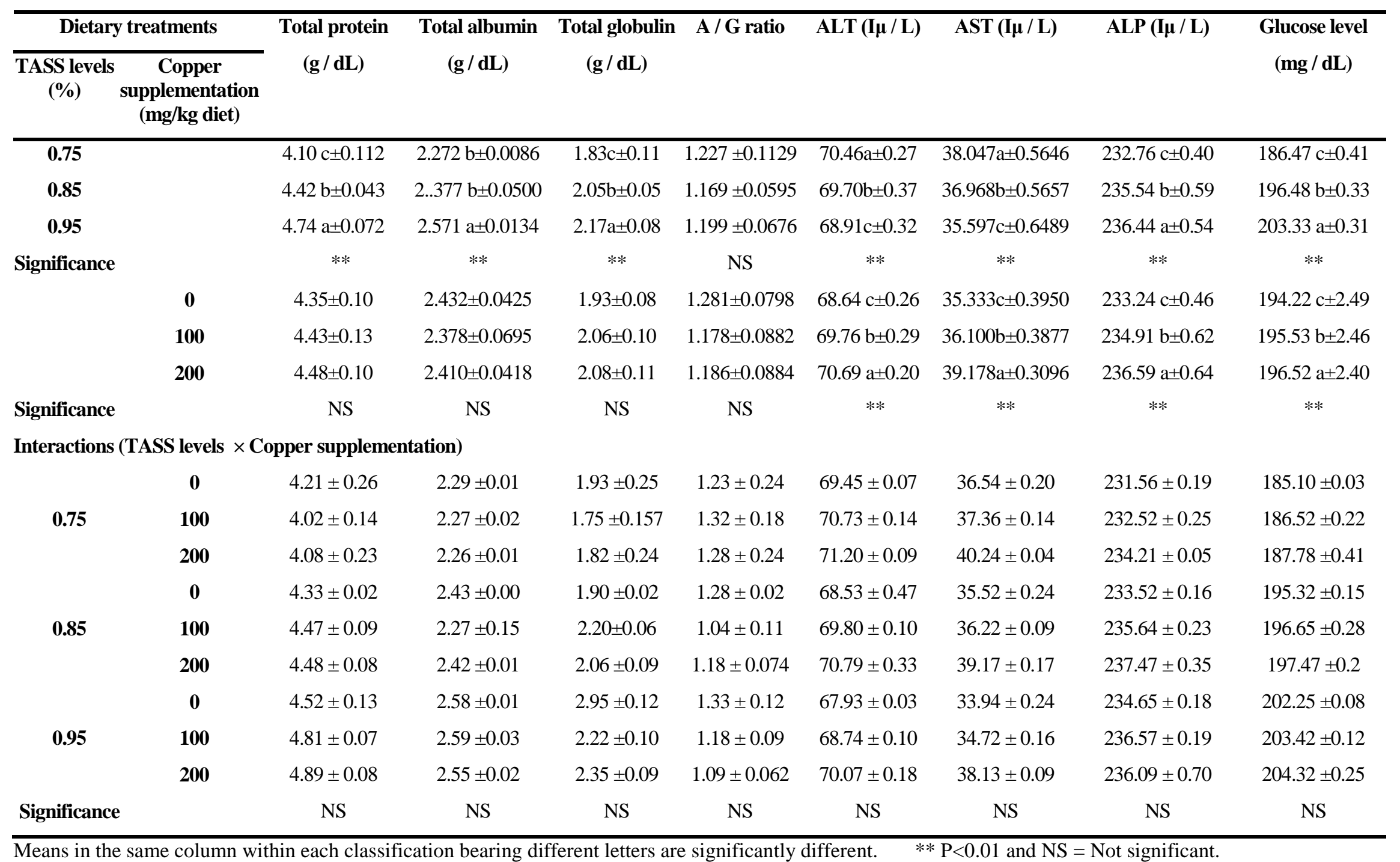




\section{Copper supplementation effect}

The results showed that no significant differences have been recorded in total protein, albumin, globulin and A / G ratio concentrations with copper supplementation levels (Table 7).

These results agreed with those obtained by El Sayed and Wakwak (2010) who found that there were no significant effects on serum total protein, albumin and globulin concentrations of chicks that fed on a diet with 0,200 and 400 ppm of CuSO4 while the concentrations were significantly high in those fed on a diet with 300 ppm of CuSO4. Moreover, Ibrahim and AbouKassem (2013) found that plasma protein profile showed insignificant differences between treatment groups at all levels of copper sulfate.

However the results contrary to Almansour (2006) who reported that a significant increase had been observed in total protein with the high dose of the $\mathrm{Cu}$ supplementation.

\section{Interaction effect (dietary TSAA level $x$ copper supplementation)}

The results in Table 7, did not show any effects on blood protein and its fractions due to the interaction between dietary TSAA level and copper supplementation.

These results are in full agreement with those of Ibrahim and Abou-Kassem (2013) who reported that there were no significant effects on protein and its fractions due to the interaction between dietary TSAA level and copper supplementation.

\section{Liver Function}

\section{Total sulpher amino acid effect}

TSAA effect on the liver function at the end of the whole experimental period (6 weeks of age) is shown in Table 7.

The blood concentrations of (ALT, AST, ALP and glucose) were significantly $(\mathrm{P}<0.01)$ affected by the increasing of TSAA level. Although, the result observed a negative significant effect on ALT and AST concentrations, however, there was a positive significant effect on ALP and glucose concentrations.

These results are in agreement with $\mathrm{El}$ Yamany et al. (2003) who showed that methionine supplementation significantly decreased AST in serum. However, ALT in serum did not affected with dietary methionine supplementation. Ibrahim and Abou-Kassem (2013) reported that the activity of AST and ALT significantly decreased with the level of $0.95 \%$ methionine than the other levels. Saki et al. (2015) studied the blood parameters of laying hens in response to various levels of methionine and protein and noticed that glucose concentration was significantly increased by treatment containing $0.35 \%$ of methionine compared with $0.25 \%$ of methionine.

The present results disagree with Chattopadhyay et al. (2006) who made a comparative efficacy of dl-methionine and herbal methionine on performance of broiler chicken and reported that concentration of AST and ALT was in normal range throughout the experimental period.

\section{Copper supplementation effect}

The data reflecting the average liver function studied on Japanese quail chicks as affected by $\mathrm{Cu}$ supplementation, irrespective of TSAA level at the end of whole experimental period are shown in Table 7.

The blood concentrations of (ALT, AST, ALP and glucose) were significantly $(\mathrm{P}<0.01)$ affected by the increasing of copper level, the results observed a positive significant effect on ALP, ALT, AST and glucose concentrations. The highest $(\mathrm{P}<0.01)$ liver enzymes were recorded for the chicks fed $200 \mathrm{mg}$ copper / kg followed by $100 \mathrm{mg}$ copper / kg compared with the control group ( $0 \mathrm{mg}$ copper / kg).

The results obtained in the present study, confirmed with those of Almansour (2006) who reported that ALT, AST levels were significantly increased by $\mathrm{Cu}$ supplementation.

However, the results are contrary to Abaza et al. (2009) who reported that the added CuSO4 at level of 100 and $200 \mathrm{mg} / \mathrm{kg}$ diet did not affect on glucose values of laying Japanese quail.

The increase of AST and ALT activity indicated gross hepatic damage. Hepatocytes are virtually the only cells with high ALT content. Hence, increase of ALT in the serum has a high specificity for liver damage. Although, both AST and ALT are excellent indicators of damage to the liver, the increase of ALP is also linked with liver damage and cause hepatitis, 
bile duct obstruction and biliary cirrhosis (Sacher and McPherson, 1991). The increase of these enzymes clearly demonstrated that the treatment with $\mathrm{CuSO}_{4}$ disrupts the liver function, more intensely at the higher doses.

\section{Interaction effect (dietary TSAA level $\times$ copper supplementation)}

No significant differences were observed among levels of TSAA and their interaction with copper supplementation on the liver function, as clarified in Table 7.

These results are in agreement with Ibrahim and Abou-Kassem (2013) who reported that there were no significant effects on ALT, AST, ALP and glucose concentration due to the interaction between dietary TSAA level and copper supplementation.

\section{REFERENCES}

Abaza, I.M., W. Ezzat, M.S. Shoeib, A.A. ElZaiat and I.I. Hassan (2009). Effects of copper sulfate on productive, reproductive performance and blood constituents of laying Japanese quail fed optimal and sub-optimal protein. Int. J. Poult. Sci., 8 (1): 80-89.

Alagawany, M., M.M. El-Hindawy and A.I. Attia (2014). Impact of protein and certain amino acids levels on performance of growing Japanese quails. Universal J. Appl. Sci., 2(6): 105-110.

Almansour, M.I. (2006). Biochemical effects of copper sulphate, after chronic treatment in quail. J. Biol. Sci., 6 (6): 1077 - 1082.

Arias, V.J. and E.A. Koutsos (2006). Effects of copper source and level on intestinal physiology and growth of broiler chickens. J. Poult. Sci., 85 : 999-1007.

Bakalli, R.L., M.G. Pesti, L.W. Ragland and V. Konjufca (1995). Dietary copper in excess of nutritional requirement reduces plasma and breast muscle cholesterol in chickens. Poult. Sci., 74: 360 - 365.

Baker, H.D., J. Odle, A.M. Funk and M.T. Wieland (1991). Bioavailability of copper in cupric oxide, cuprous oxide and in copperlysine complex. Poult. Sci., 70:177 - 179.
Banks, K.M., K.L. Thompson, J.K. Rush and T.J. Applegate (2004). Effects of copper source on phosphorus retention in broiler chicks and laying hens. J. Poult. Sci., 83: 990-996.

Chattopadhyay, K., M.K. Mondal and B. Roy (2006). Comparative Efficacy of DLMethionine and Herbal Methionine on Performance of Broiler Chicken. Int. J. Poult. Sci., 5 (11): 1034-1039.

Christmas, R.B. and R.H. Harms (1984). The value of protein, methionine or other nutrients for the alleviation of copper toxicity in the broiler chick diet. Nut. Rep. Int., 29:1217-1222.

Chowdhury, S.D., I.K. Paik, H. Namkung and H.S. Lim (2004). Responses of broiler chickens to organic copper fed in the form of copper-methionine chelate. Anim. Feed Sci. Technol., 115:281-293.

Corrêa, G.S.S., M.A. Silva, A.B. Corrêal, V. Almeida, D.O. Fontes, R.A. Torres, N.J.L. Dionello, R.V. Freitas, A.A. ventura, J.V. Paulo, Silva and G.G. Santos (2006). Total methionine + cystine requirement for meat type quails during the growing phase. Arq. Bras. Med. Vet. Zootec., 58 (3): 414-420.

Dozier, W.A., A.J. Davis, M.E. Freeman and T.L. Ward (2003). Early growth and environmental implications of dietary zinc and copper concentrations and sources of broiler chicks. Br. Poult. Sci., 44:726-731.

Duncan, D.B. (1955). Multiple Range and Multiple F-Test, Biometrics, 11:1-42.

El-Anwar, E.M.M. and A.I. Attia (2005). Productive and economical performance of broiler chicks fed diets contained different levels of protein and total sulfur amino acid during winter season of Egypt. Egyptian J. Appl. Sci., 20: 1-14.

El Sayed, M.A. and M.M. Wakwak (2010). Effects of copper sulphate on productive, reproductive performance and some of blood constituents of laying Japanese quail. Egyptian J. Nut. and Feeds, 9 (1): 43 - 53.

El Yamany, A.T., F.E. Eman and A.A. El Ghamry (2003). Substitution of soybean 
seeds with or without DL methionine addition on some productive performance, metabolic responses and economic efficiency in growing Japanese quail. Egypt. Poult. Sci., 23: 807 - 824.

Ewing, H.P., G.M Pesti, R.I. Bakalli and J.F. M. Menten (1998). Studies on the feeding of cupric sulfate pentahydrate, cupric citrate and copper oxychloride to broiler chickens. Poult. Sci., 77: 445-448.

Fritts, C.A. (2001). Relationship of dietary lysine level to the concentration of ahh essential amino acids in broiler diets. Poult. Sci., 80:1472-1479.

Hassan, I.I. (1999). Effect of some nutritional treatments on broiler rations. Ph. D. Thesis, Fac. Agric., Zagazig Univ., Egypt.

Ibrahim, A.Z. and D.E. Abou-Kassem (2013). Effect of interaction between copper sulfate and total sulfur amino acid levels on performance, liver function, digestive enzymes activity and some blood parameters of growing Japanese quail. Egyptian J. Nut. and Feeds, 15 (3): 631-647.

Jensen, L.S. and D. V. Maurice (1978). Effect of methionine on copper-induced growth depression and gizzard erosion. Poultry Sci., 57: 1530-1532.

Jensen, L.S. and D. V. Maurice (1979). Influence of sulfur amino acids on copper toxicity in chicks. J. Nut., 91-97.

Kassim, H. and S. Suwanpradit (1996). The influence of copper on the total sulpher amino acids requirement of broilers during two growing periods. Ajas, 9 (4): 359-361.

Karimi, A., Gh. Sadeghi and A. Vaziry (2011). The effect of copper in excess of the requirement during the starter period on subsequent performance of broiler chicks. J. Appl. Poult. Res., 20: 203-209.

Kim, G.B., Y.M. Seo, K.S. Shin, A.R. Rhee, J. Han and I.K. Paik (2011). Effects of supplemental copper-methionine chelate and copper-soy proteinate on the performance, blood parameters, liver mineral content, and intestinal microflora of broiler chickens. J. Appl. Poult. Res., 20: 21-32.
Klasing, C.K. (1998). Minerals. Pages 234-276 in Comparative Avian Nutrition. CAB Int., New York, NY.

Konjufa, V.H., G.M. Pesti and I.R. Bakalli (1997). Modulation of cholesterol levels in broiler meat by dietary garlic and copper. Poult. Sci., 76:1264-1271.

Makled, M.N., M.A. El-deep and N.H. Abdallah (2001). Effect of genotype, methionine level and season on performance of growing indigenous Naked neck (Sharkas chickens). Eygpt Poult. Sci. J., 21:1-25.

NRC (1994). National Research Council. Nutrient requirements of poultry. $9^{\text {th }}$ Ed., Nat. Acad. Sci. Washington, DC., USA.

Paik, I.K. (2001). Application of chelated minerals in animal production. Asian Austral. J. Anim. Sci., 14:191 - 198.

Pang, Y. and T.J. Applegate (2007). Effects of dietary copper supplementation and copper source on digesta $\mathrm{pH}$, calcium, zinc and copper complex size in the gastrointestinal tract of the broiler chicken. Poult. Sci., 86: 531-537.

Prajapati, A.P., V. Mudgal, S. Srivastava, JK Bharadwaj and R.P. Nema (2012). Effect of copper supplementation on the performance of coloured meat type birds. Int. J. Vet. Sci. 1 (3): 108-111.

Pesti GM and RI Bakalli (1996). Studies on the feeding of cupric sulfate pentahydrate and cupric citrate to broiler chickens. Poult. Sci., $75: 1086-1091$.

Robbins, K.S. and D.H. Baker (1980). Effect of sulpher amino acid level and source on the performance of chicks fed high levels of copper. Poult. Sci., 59:1246-1253.

Sacher, R.A. and R.A. McPherson, (1991). Widmann's Clinical Interpretation of Laboratory Tests. $10^{\text {th }}$ Ed., F.A. Davis Company, Philadelphia, 348 (401): 422-442.

Saki, A.A., P. Zamani, M. Haghi, H. Aliarabi, M. Malecky, E. Rahmatnejad, S. Mirzaie and E. Ahmad (2015). Molecular aspects, blood parameters, bone mechanical properties, and performance of laying hens in response to 
various levels of methionine and protein. Revue Med. Vet., 166: 47 - 53.

SAS (1988). Institute SAS/STA User"s Guide. Release 6.03 Edition. SAS Inst., Inc., Cary, NC.

Shrivastav, A.K. and B. Panda (1986). Sulphur amino acid requirement of growing Japanese quail. Indian. J. Anim. Sci., 57:1303-1305.

Skrivan, M., V. Skrivanova, M. Marounek E. Tumova and J. Woli (2000). Influence of dietary fat source and copper supplementation on broiler performance, fatty acid profile of meat and depot fat, and on cholesterol content in meat. Poult. Sci., 41:608- 614 .

Skřivan, M., S. Ševčíková, E. Tůmová, C.V. Skřivanová and M. Marounek (2002). Effect of copper sulphate supplementation on performance of broiler chickens, cholesterol content and fatty acid profile of meat.
Snedecor, C.W. and W.C. Cochran (1982). Statistical Methods. $7^{\text {th }}$ Ed. Iowa State Coll Press Ames IA.

Svacha, A., C.W. Weber and B.L. Reid (1970). Lysine, methionine and glycine requirements of Japanese quail to five weeks of age. Arizona Agric. Exp. Station J. Article., 1528: 54-59.

Waldroup, P.W., C.A. Fritts and F.L. Yan (2003). Utilization of bio-mas mannan oligosaccharide and bioplex copper on broiler diets. Int. J. Poult. Sci., 62 (1):44-52.

Wang, J.S., S.R. Rogers and G.M. Pasti (1987). Influence of choline and sulphate on copper toxicity and substitution of and antagonism between methionine and cooper supplements to chick diets. Poult. Sci., 66: 228-236.

Zahedi, M., J.G. Ghalehkandi, Y. Ebrahimnezhad ad F. Emami (2014). Effects of different levels of copper sulfate on performance in Japanese quail (Coturnix coturnix japonica). Int. J. Bio., 4 (1) : 387-392. 
أداء النمـو وبعض صفات الام للسمان الياباني وتأثره بالأحماض الأمينية الكبريتية وإضافة النحاس

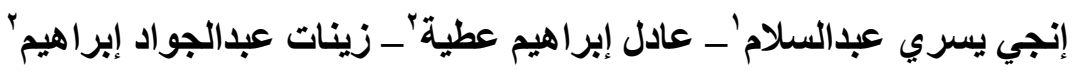

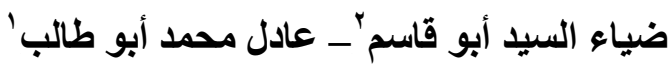

1 ـ وحدة بحوث الدو اجن ـ قسم التطبيقات البيولوجية ـ مركز البحوث النووية ـ هيئة الطاقة الذرية المصرية ـ مصر

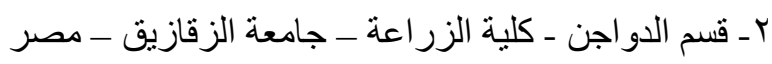

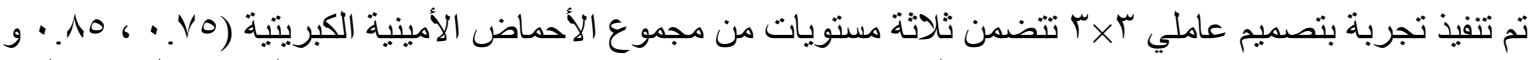

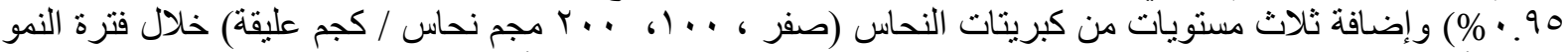

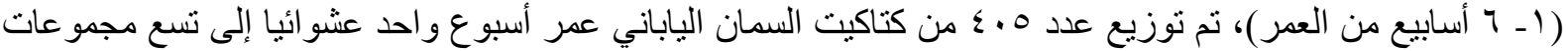

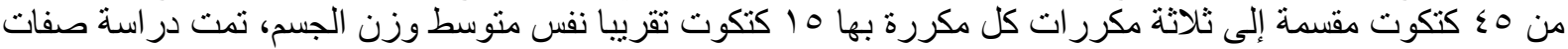

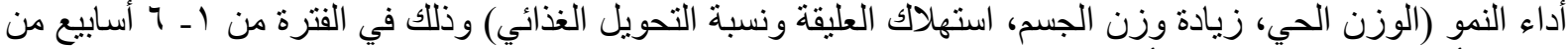

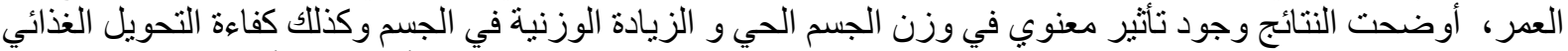

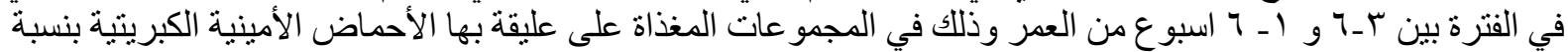

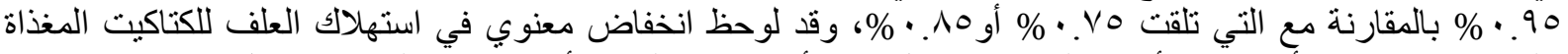

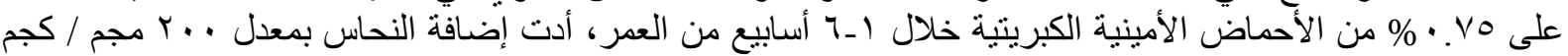

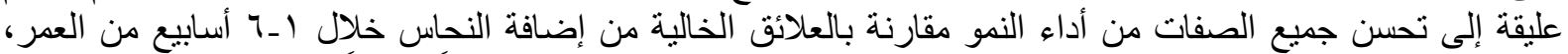

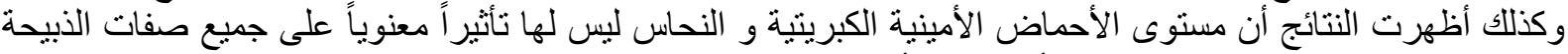

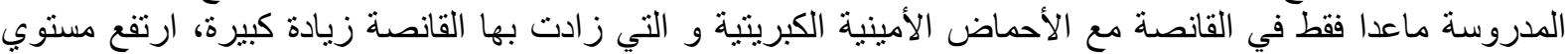

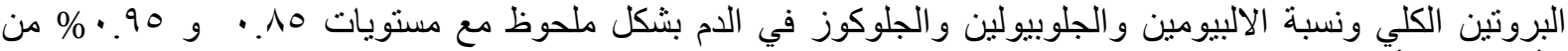

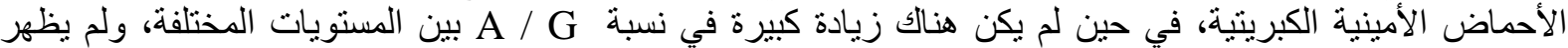

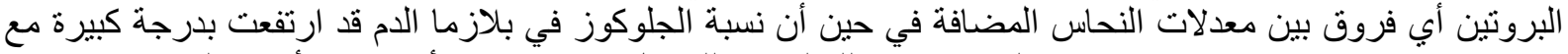

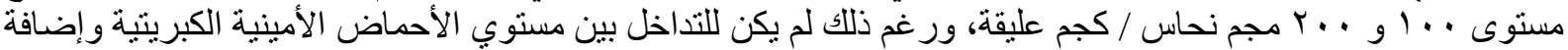

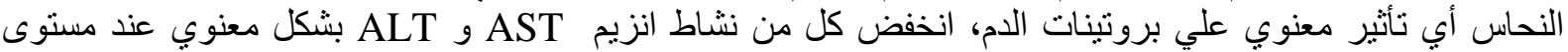

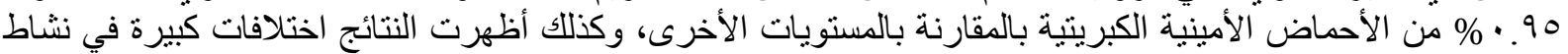

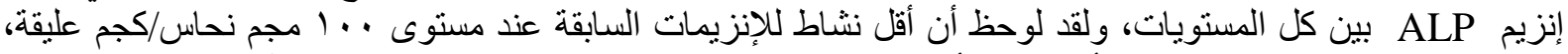

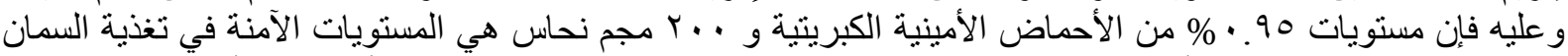

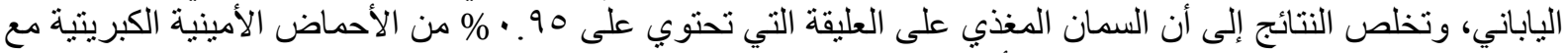

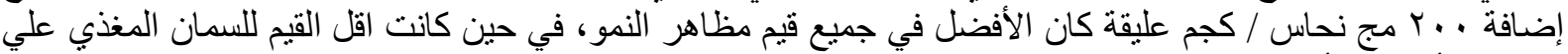

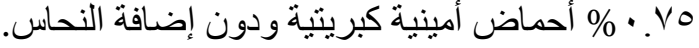

أستاذ الدو اجن ـ كلية الزر اعة ـ جامعة القاهرة. أستاذ رعاية الدو اجن المتفرغ ـ كلية الزر اعة اعة - جامعة الزقازيق. 
